\title{
DAYA HAMBAT EKSTRAK KULIT MANGGIS (GARCINIA MANGOSTANA L.) TERHADAP STREPTOCOCCUS MUTANS
}

\author{
${ }^{1}$ Julian G. Komansilan \\ ${ }^{2}$ Christy N. Mintjelungan \\ ${ }^{3}$ Olivia Waworuntu
}

\author{
${ }^{1}$ Kandidat Skripsi Program Studi Pendidikan Dokter Gigi Fakultas Kedokteran \\ ${ }^{2}$ Program Studi Pendidikan Dokter Gigi Universitas Sam Ratulangi Manado \\ E-mail: ianway71@gmail.com
}

\begin{abstract}
Latin is called Garcinia mangostana Linn identical with the nickname queen tropical fruit (Queen of tropical fruit) is a plant that can be utilized all its parts, including the skin of the fruit. Dental caries is an oral disease that often occurs. Streptococcus mutans is one of the causes of dental caries. This study is an experimental laboratory, using pure experimental designs (true experimental design) with a post-test only research design control design conducted in the Laboratory of Microbiology General Hospital Prof. DR. R.D. Kandou Manado in December 2014-May 2015 with research subjects using Streptoccocus mutans bacteria and as a research sample taken mangosteen peel extract (Garcinia mangostana L) were extracted using maceration method by ethanol $90 \%$. The result showed the average broad zones of inhibition of mangosteen peel extract against Streptococcus mutans amounted at $669.42 \mathrm{~mm} 2$. Results of statistical calculations with independent t-test test is known that there were significant differences between groups of mangosteen peel extract and the control group $(\mathrm{P}<0.05)$.From this study it can be concluded that the mangosteen peel extract (Garcinia mangostana L.) has an antibacterial effect in inhibiting the growth of Streptococcus mutans bacteria. Wide zone of inhibition of mangosteen peel extract (Garcinia mangostana L.) is smaller than the broad zone of inhibition of antibiotics.
\end{abstract}

Keywords: skin extract mangosteen (garcinia mangostana l.), streptoccocus mutans

\begin{abstract}
Abstrak: Buah manggis yang dalam bahasa latin disebut Garcinia mangostana Linn yang identik dengan julukan ratu buah tropis (Queen of tropical fruit) merupakan tanaman yang seluruh bagiannya dapat dimanfaatkan, termasuk kulit buahnya. Karies gigi merupakan penyakit gigi dan mulut yang sering terjadi. Streptococcus mutans merupakan salah satu penyebab karies gigi. Penelitian ini merupakan penelitian eksperimental laboratorium, menggunakan rancangan eksperimental murni (true experimental design) dengan rancangan penelitian post test only control design yang dilakukan di Laboratorium Mikrobiologi Rumah Sakit Umum Prof. DR. R. D. Kandou Manado pada bulan Desember 2014-Mei 2015 dengan subjek penelitian mengunakan bakteri Streptoccocus mutans dan sebagai sampel penelitian diambil ektrak kulit manggis (Garcinia mangostana $L$ ) yang diekstraks menggunakan metode maserasi dengan pelarut etanol $90 \%$. Hasil penelitian didapatkan rata-rata luas zona hambat ekstrak kulit manggis terhadap Streptococcus mutans sebesar sebesar $669.42 \mathrm{~mm}^{2}$. Hasil perhitungan statistik dengan uji independent t-test diketahui terdapat perbedaan yang bermakna antara kelompok ekstrak kulit manggis dan kelompok kontrol $(\mathrm{P}<0.05)$. Dari penelitian ini dapat disimpulkan bahwa ekstrak kulit manggis (Garcinia mangostana L.) memiliki efek antibakteri dalam menghambat pertumbuhan bakteri Streptococcus mutans. Luas zona hambat dari ekstrak kulit manggis (Garcinia mangostana L.) lebih kecil dibandingkan dengan luas zona hambat dari antibiotik.
\end{abstract}

Kata kunci: ektrak kulit manggis (garcinia mangostana l.), streptoccocus mutans 
Buah Manggis yang dalam bahasa latin disebut Garcinia mangostana Linn yang identik dengan julukan ratu buah tropis (Queen of tropical fruit) merupakan tanaman yang seluruh bagiannya dapat dimanfaatkan, termasuk kulit buahnya. ${ }^{1}$ Beberapa hasil penelitian yang telah dilakukan menyatakan terdapat banyak manfaat dari kulit Manggis, manfaatmanfaat tersebut meliputi penggunaan untuk tujuan kecantikan dan kesehatan. ${ }^{2}$

Saat ini terdapat banyak olahan dari ekstrak kulit buah Manggis yang menghasilkan berbagai bentuk produk, sebagai contoh ialah kapsul serbuk kulit manggis dan jus kulit manggis yang sudah beredar di masyarakat. Dari berbagai produk yang beredar, Xhanton yang terdapat dalam ekstrak kulit manggis paling banyak digunakan sebagai bahan utama. ${ }^{3}$

Beberapa penelitian menunjukkan bahwa xhanton memiliki aktivitas antioksidan, antiinflamasi, antialergi, antibakteri, antifungi, antitumor, dan antivirus. Hal tersebut yang membuat kulit manggis semakin populer. ${ }^{4}$ Xhanton merupakan komponen antioksidan paling penting dalam kulit Manggis, kandungan xhanton pada kulit buah manggis 27 kali lebih banyak daripada yang terkandung di dalam daging buah Manggis. $^{5}$ Karies gigi merupakan penyakit gigi dan mulut yang sering terjadi. Di Provinsi Sulawesi Utara berdasarkan data dari Dinas Kesehatan Sulawesi Utara tahun 2013, menunjukan jumlah pengunjung puskesmas dengan penyakit karies gigi berkisar 6407 orang atau 20\% dari jumlah penduduk di Sulawesi Utara. $^{6}$ Streptococcus mutans merupakan salah satu penyebab karies gigi $^{7}$, karena bisa bertahan hidup dari suatu kelompok karbohidrat yang berbeda saat gula yang dimetabolisme dan sumber energi lainya, mikroba menghasilkan asam yang perlahan menghancurkan email kemudian menjadi karies pada gigi .
Penelitian Keyes pada binatang bebas mikroorganisme memperlihatkan bahwa plak yang didominasi oleh kuman bakteri Streptococcus mutans dan Lactobacillus menyebabkan terbentuknya karies. Streptococcus mutans merupakan mikroorganisme yang kariogenik karena mampu segera membentuk asam dari karbohidrat yang dapat diragikan. Mikroorganisme tersebut dapat tumbuh subur dalam suasana asam dan dapat menempel pada permukaan gigi. ${ }^{9}$

Berdasarkan beberapa manfaat dari kulit buah manggis yang berkaitan dengan kedokteran gigi, maka peneliti tertarik untuk melakukan penelitian tentang daya hambat ekstrak kulit manggis (Garcinia mangostana L.) terhadap Streptococcus mutans yang merupakan mikroorganisme penyebab tersering pada karies gigi.

\section{BAHAN DAN METODE PENELITIAN} Penelitian ini merupakan penelitian eksperimental laboratorium, menggunakan rancangan eksperimental murni (true experimental design) dengan rancangan penelitian post test only control design. Penelitian ini dilaksanakan di Laboratorium Mikrobiologi Rumah Sakit Umum Prof. DR. R. D. Kandou Manado pada bulan Desember 2014-Mei 2015. Subjek dari penelitian ini ialah bakteri Streptococcus mutans. Variabel bebas ialah ekstrak kulit manggis (Garcinia Mangostana L.), dan Amoksisilin dengan pelarut akuades. Variabel terikat ialah bakteri Streptococcus mutans. Streptococcus mutans merupakan bakteri murni yang diperoleh dari Laboratorium Mikrobiologi RSUP Prof. DR. R. D. Kandou Manado. Ekstrak kulit manggis (Garcinia Mangostana L.) yakni ekstrak yang didapat dengan cara mengekstraksi kulit manggis (Garcinia Mangostana L.) dengan metode maserasi menggunakan pelarut etanol 96\%. Amoksisilin 
merupakan antibiotik yang tersedia dalam bentuk tablet di Laboratorium Mikrobiologi RSUP Prof. DR. R. D. Kandou Manado. Alat-alat yang digunakan dalam penelitian ini yaitu tabung reaksi, jarum ose, petridish, pinset, kapas lidi steril, pipet, oven, autoclave, inkubator, tabung reaksi, spidol, kamera, batang pengaduk, timbangan, api bunsen, jangka sorong, kompor, sendok plastik, sarung tangan, vacuum evaporator, tabung erlenmeyer, masker, dan kertas saring. Bahan-bahan yang digunakan dalam penelitian ini yaitu ekstrak kulit manggis (Garcinia Mangostana L.), bakteri Streptococcus mutans, Nutrient Agar (NA), Agar Muller-Hinton (MHA), brain heart infusion broth (BHI-B), etanol 96\%, Amoksisilin, larutan $\mathrm{BaCl} 2$ 1\%, larutan H2SO4 1\%, akuades. Alat-alat yang digunakan dalam penelitian ini disterilkan terlebih dahulu. Alat-alat gelas disterilkan dalam oven pada suhu $170^{\circ} \mathrm{C}$ selama 1 jam (sterilisasi kering). Media disterilkan dalam autoclave pada suhu $121^{\circ} \mathrm{C}$ selama 15 menit (sterilisasi basah). Sampel dalam penelitian ini ialah kulit buah manggis yang diperoleh dari Kecamatan Tinoor, kota Tomohon, Sulawesi Utara. Ekstrak kulit manggis diperoleh dengan cara; buah manggis dibersihkan dan dipisahkan kulit luar dan daging buah, kulit buah dipotongpotong dan dikeringkan dengan cara dijemur, dihaluskan dengan menggunakan alat blender sampai diperoleh serbuk kulit manggis yang halus. Setelah diperoleh hasil berupa serbuk halus dari kulit buah Manggis, kemudian diekstrak dengan cara; ditimbang 350 gram serbuk kulit manggis, dimasukan dalam toples dan dimaserasi dengan etanol 96\% sebanyak $2625 \mathrm{ml}$ sampai serbuk sampel terendam, ditutup dan dibiarkan selama 5 hari sambil sesekali diaduk kemudian maserat disaring ke dalam toples. ampas dibilas menggunakan etanol $90 \%$ sampai memperoleh maserat $3500 \mathrm{ml}$ dan tutup wadah. dibiarkan di tempat sejuk terlindung dari cahaya matahari selama 2 hari. Maserat disaring kemudian dipekatkan menggunakan rotavapor. Maserat dikeringkan dalam oven suhu $50^{\circ} \mathrm{C}$ hingga diperoleh ekstrak kering. Bakteri Streptococcus mutans yang digunakan dalam penelitian ini diperoleh dari stok bakteri murni yang diperoleh dari Laboratorium Mikrobiologi RSUP Prof. DR. R. D. Kandou Manado. Bakteri ini disimpan pada agar miring kemudian dimasukan ke dalam wadah steril yang berada dalam suasana anaerob dan ditutup, sehingga sterilisasi terjaga. Jika sudah mendekati waktu untuk digunakan, bakteri diinkubasi dalam inkubator pada suhu $37^{\circ} \mathrm{C}$. Nutrient Agar (NA) sebanyak 23 gram dilarutkan dengan 1 liter akuades menggunakan tabung Erlenmeyer, kemudian dihomogenkan dan dituang ke dalam tabung reaksi steril yang ditutup dengan alumunium foil. Media yang telah steril dibiarkan pada suhu ruangan selama 30 menit sampai media memadat pada kemiringan $30^{\circ} \mathrm{C}$.

Media Brain Heart Infusion Broth (BHI-B) ditimbang sebanyak 37 gram dan dilarutkan dalam 1 liter akuades dalam tabung Erlenmeyer. Media disterilisasi dalam autoclave pada suhu $121^{\circ} \mathrm{C}$ selama 15 menit, selanjutnya dituang dalam tabung reaksi sebanyak $7 \mathrm{ml}$. Agar Muller-Hinton (MHA) ditimbang sebanyak 28 gram menggunakan 1 liter akuades sebagai pelarut. Media disterilisasi dalam autoclave pada suhu $121^{\circ} \mathrm{C}$ selama 15 menit, selanjutnya dimasukkan dalam cawan petri sebanyak $10 \mathrm{ml}$ dan dibiarkan hingga mengeras. Lapisan berikutnya dituang media yang sama sebanyak $20 \mathrm{ml}$. Larutan baku McFarland terdiri atas dua komponen yaitu larutan $\mathrm{BaCl} 2$ 1\% dan $\mathrm{H} 2 \mathrm{SO} 4$ 1\%. Larutan $\mathrm{BaCl} 21 \%$ sebanyak 0,05 ml dicampur dengan larutan $\mathrm{H} 2 \mathrm{SO} 4 \quad 1 \%$ sebanyak 9,95 ml dan dikocok homogen. Nilai absorban larutan baku McFarland 0,5 
ekuivalen dengan suspensi sel bakteri dengan konsentrasi 1,5 x $108 \mathrm{CFU} / \mathrm{ml}$.

Bakteri Streptococcus mutans yang disimpan di media agar yang berasal dari biakan murni rongga mulut pasien poli gigi di Rumah Sakit Umum Prof. dr. R. D. Kandou Manado, diambil dengan menggunakan jarum ose steril, lalu ditanamkan pada media agar miring dengan cara menggores. Bakteri yang telah digores pada media agar, diinkubasi diambil koloninya dari media agar miring dengan menggunakan jarum ose steril. Koloni yang diambil diamasukan kedalam media BHI-B sampai kekeruhannya sama dengan standard McFarland. Lidi kapas steril dicelupkan kedalam bakteri suspense hingga basah. Lidi kapas diperas dengan menekankan pada dinding tabung reaksi bagian dalam, kemudian digores merata pada media MHA. Kontrol positif dibuat dengan sediaan bubuk obat amoksisilin. Pembuatan larutan ini mengacu pada minimal inhibitory concentration (MIC) amoksisilin terhadap Streptococcus mutans, yakni 2,0178 mg/ml yang dicampur dengan pelarut akuades hingga homogen. Metode pengujian yang digunakan ialah metode modifikasi Kirby-Bauer dengan menggunakan kertas saring. Kertas saring pertama dicelupkan ke dalam larutan ekstrak kulit manggis (Garcinia Mangostana L.) yang sudah dilarutkan dengan etanol 96\% dan dievaporasi dengan vacuum rotary evaporation.

Kertas saring kedua dicelupkan dengan kontrol positif yaitu amoksisilin yang sudah dilarutkan dengan akuades, dan pada kertas saring yang ketiga merupakan kontrol negatif dicelupkan kedalam akuades. Setelah itu, cawan petri diinkubasi dalam inkubator dalam suhu $37^{\circ} \mathrm{C}$ selama 24 jam.

Pengamatan dilakukan setelah 24 jam masa inkubasi. Zona bening merupakan petunjuk kepekaan bakteri terhadap bahan antibakteri yang digunakan sebagai bahan uji dan dinyatakan dengan luas zona hambat. Zona hambat yang terbentuk disekitar kertas saring diukur diameter

Data hasil penelitian dihitung secara manual, kemudian diolah menggunakan program komputer dan data yang sudah diolah disajikan dalam bentuk gambar, tabel dan tulisan.

\section{HASIL PENELITIAN}

Pengujian daya hambat dilakukan dengan mengukur diameter zona hambat yang dihasilkan pada cawan petri yang sudah diinkubasi selama 24 jam pada suhu $37^{\circ} \mathrm{C}$. Media yang sudah diinkubasi diambil dari inkubator kemudian diukur diameternya dengan menggunakan jangka sorong. Luas zona hambat dihitung dengan rumus lalu dimasukan pada tabel pengamatan zona hambat yang terbentuk bisa dilihat pada Gambar 1.

Zona hambat yang dihasilkan memiliki diameter yang berbeda-beda dan bentuk yang tidak teratur. Pengamatan dilakukan dengan mengukur luas zona hambat kemudian dihitung menggunakan rumus dan dimasukan ke dalam tabel pengamatan. Hasil pengukuran tersebut dapat dilihat pada Tabel 1.

Luas zona hambat yang terbentuk pada media Muller-Hinton Agar kemudian dihitung nilai rata-ratanya. Kelompok ekstrak kulit manggis didapatkan nilai ratarata luas zona hambat sebesar $669.42 \mathrm{~mm}^{2}$, sedangkan pada kelompok kontrol yang terbagi atas dua kelompok terdapat nilai rata-rata yaitu kelompok control positif.

Amoksisilin didapat nilai rata-rata luas zona hambat sebesar $7.051 \mathrm{~mm}^{2}$ dan nilai rata-rata pada kelompok kontrol negatif akuades sebesar $0.00 \mathrm{~mm}^{2}$. Gambaran dari hasil perhitungan dimasukan kedalam diagram untuk melihat besar perbandingan antara kelompok intervensi dan kelompok kontrol. 


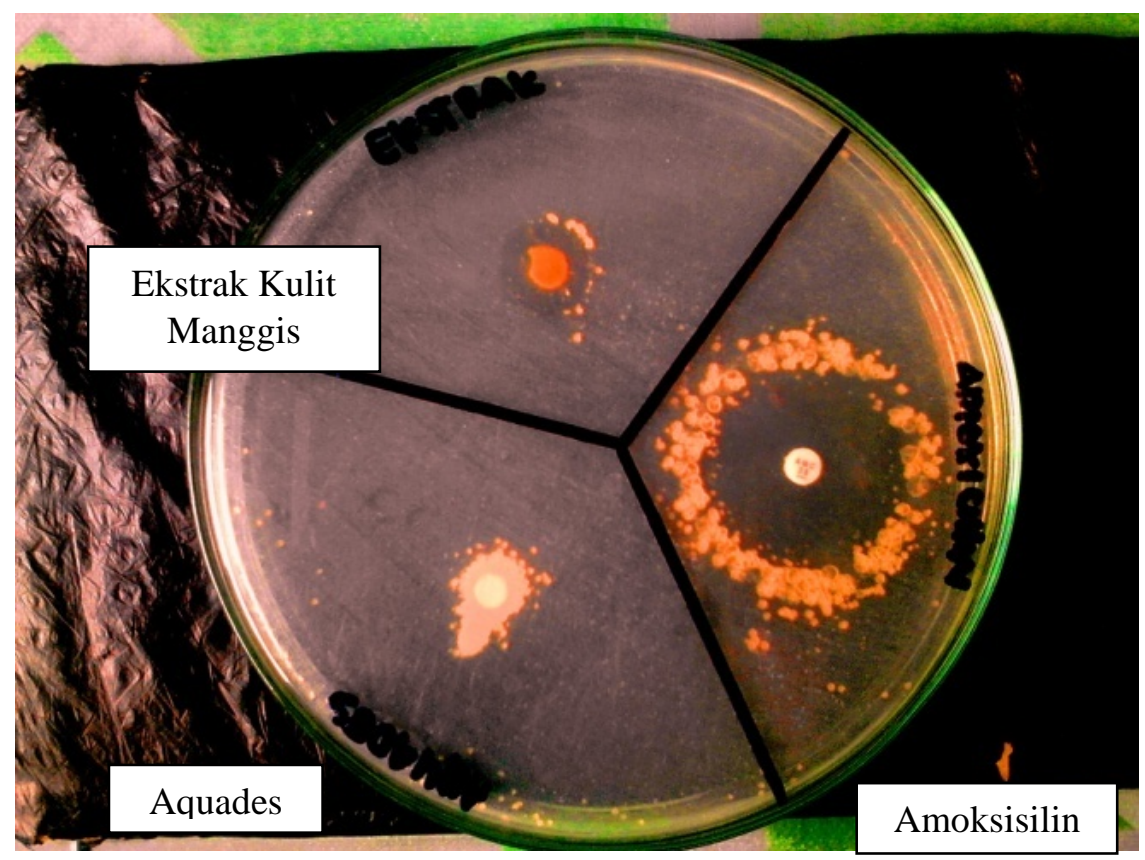

Gambar 1. Zona hambat yang terbentuk pada media Agar Muler-Hinton

Tabel 1. Luas zona hambat ekstrak kulit manggis (Garcinia mangostana L.), amoksisilin, dan aquades

\begin{tabular}{cccc}
\hline \multirow{2}{*}{ Pengulangan } & \multicolumn{3}{c}{ Luas Zona Hambat (mm) } \\
\cline { 2 - 4 } & $\begin{array}{c}\text { Ekstrak Kulit } \\
\text { Manggis }\end{array}$ & $\begin{array}{c}\text { Amoksisilin } \\
\text { (kontrol +) }\end{array}$ & $\begin{array}{c}\text { Aquades } \\
\text { (kontrol -) }\end{array}$ \\
\hline 1 & 201,14 & 2.469 & 0 \\
2 & 314,28 & 2.291 & 0 \\
3 & 154,00 & 2.291 & 0 \\
Rerata & 669,42 & 7.051 & 0 \\
\hline
\end{tabular}

\section{BAHASAN}

Banyak masyarakat yang membuang kulit buah manggis sehingga kulit buah manggis ini dapat dikategorikan sebagai limbah, padahal pada kulit buah manggis yang mengandung air 62,05\%, abu 1,01\%, lemak $0,63 \%$, protein $0,71 \%$, total gula 1,17\%, dan karbohidrat 35,61\% dapat dimanfaatkan sebagai antimikroba, anti kanker , dan juga mempuyai daya antioksidan tertinggi. ${ }^{10}$ Kulit buah manggis mengandung senyawa xhanton yang meliputi mangostin, mangostenol, mangostinon $A$, manostenon $B$, trapezifolixhanthone, $\quad$ tovophyllin $\quad B$, alfamangostin, beta mangostin, garcinon $B$, mangostanol, flavonoid epicatechin, dan gartanin. Hasil penelitian di Jepang menunjukan ekstrak kulit buah manggis yang mengandung lebih dari $90 \%$ xhanthon (campuran alfa mangostin 80-90\% dan gama-mangostin 5-10\%) mampu berperan dalam pengobatan kanker (cancer therapeutic). ${ }^{10}$ Senyawa xhanton yang terdapat dalam kulit buah manggis mempunyai daya antioksidan tingkat tinggi yang nilainya mencapai 17.000-20.000 ORAC per 100 ons (2.835 gram kulit manggis), lebih besar dari wortel dan jeruk yang kadar ORAC-nya 300 dan 2.400. ${ }^{11}$ 
Seiring perkembangan zaman terdapat berbagai penelitian tentang ekstrak kulit manggis yang dikenal kaya akan antioksidan yang sangat tinggi ini mempunyai aktivitas anti mikroba terhadap beberapa jenis jamur (Fusarium oxysporum, Alternaria tenuis, dan Dreschlra oryzae) dan bakteri (Staphylococcus aureus). Terdapat begitu banyak pengembangan untuk penelitian lebih lanjut tentang berbagai manfaat dari kulit manggis ini sebagai anti mikroba. ${ }^{12}$

Penelitian ini merupakan uji eksperimental untuk mengetahui adanya daya hambat dari ekstrak kulit manggis terhadap Streptococcus mutans. Penelitian ini dilakukan dengan cara membiakkan bakteri Streptococcus mutans dalam media Muller-Hinton Agar disertai dengan pelekatan cakram kertas saring yang diberi ekstrak kulit manggis (Garcinia mangostana L.) dan juga antibiotik amoksisilin sebagai kontrol positif dan akuades sebagai kontrol negatif, lalu diinkubasi ke dalam inkubator dengan suhu 370 C selama 24 jam. Zona hambat yang terlihat disekitar cakram kertas saring ekstrak kulit manggis (Garcinia mangostana L.) menunjukan bahwa ekstrak kulit manggis (Garcinia mangostana L.) mampu menghambat pertumbuhan bakteri Streptococcus mutans.

Berdasarkan hasil pengamatan, dilakukan tiga kali pengujian dengan cakram kertas saring yang diberi ekstrak kulit manggis (Garcinia mangostana L.), dan semua pengujian tersebut menunjukan adanya zona hambat disekeliling cakram tersebut. Apabila dibandingkan dengan zona hambat di sekeliling antibiotik amoksisilin luas zona hambat ekstrak kulit manggis (Garcinia mangostana L.) lebih kecil, sedangkan kertas saring yang dicelupkan kedalam akuades sebagai kontrol negatif sama sekali tidak membentuk zona hambat.
Uji statistik yang digunakan dalam penelitian ini yaitu independent t-test. Uji statistik independent t- test digunakan untuk membandingkan selisih dua rata-rata (mean) dari dua sampel yang indepen dendengan asumsi data berdistribusi normal. Table Group Statistic memperlihatkan rata-rata luas zona hambat cakram yang diberi kulit manggis 223.14 $\mathrm{mm}^{2}$ (SD \pm 82.37), sedangkan kontrol positif antibiotik Amoxcicillin 2348.66 $\mathrm{mm}^{2}$ (SD \pm 99.88), selain itu luas zona hambat cakram aquades sebagai kontrol negatif menunjukan $0.00 \mathrm{~mm}^{2}$. Hasil uji homogenitas menunjukan bahwa efektifitas antara kulit manggis, amoxcicillin, dan akuades terhadap Streptococcus mutans memiliki varian yang berbeda $\mathrm{p}>0.05$, sehingga dalam pengujian Independent ttest selanjutnya menggunakan nilai equal variances non assumed. Kriteria pengujian jika $-\mathrm{t}$ tabel $\leq \mathrm{t}$ hitung $\leq \mathrm{t}$ tabel maka Ho diterima, sebaliknya Ho ditolak jika -t hitung $<-\mathrm{t}$ tabel atau $\mathrm{t}$ hitung $>\mathrm{t}$ table. Penentuan $\mathrm{t}$ tabel dilihat dalam tabel statistic pada signifikansi $0.05: 2=0.025$ dengan derajat kebebasan (df) n-2 atau6-2= 4, hasil diperoleh untuk t tabel sebesar 2.776 .

Hasil penelitian menunjukan nilai $\mathrm{t}$ hitung untuk efektivitas kulit manggis dengan amoxcicillin sebagai kontrol positif terhadap bakteri Streptococcus mutans 28,436<2.776 dan nilai $\mathrm{t}$ hitung untuk efektivitas kulit manggis dan aquadest terhadap bakteri Streptococcus mutans 4.692>2.776 sebagai control negatif. Berdasarkan hasil ini maka dapat disimpulkan bahwa Ho ditolak artinya terdapat perbedaan yang bermakna antara luas zona hambat dari ekstrak kulit Manggis dengan kontrol positif antibiotik amoxcicillin serta akuades sebagai kontrol negatif.

Hasil penelitian ini sama dengan hasil penelitian sebelumnya yang dilakukan oleh 
Siti, Dian, dan Joko. Penelitiannya dilakukan dengan cara serbuk kulit manggis ditambah etil asetat kemudian dilakukan proses ekstraksi dengan cara maserasi dan diujikan pada bakteri streptococcus mutans. Hasilnya menunjukan bahwa ekstrak etil asetat kulit buah Manggis (Garcinia mangostana L.) mampu menghambat pertumbuhan Streptococcus mutans. ${ }^{4}$

Berdasarkan hasil penelitian ini menunjukan bahwa ekstrak kulit Manggis memiliki daya hambat terhadap bakteri Streptococcus mutans, jika dibandingkan zona hambat yang dihasilkan kontrol positif Amoksisilin lebih besar daripada zona hambat yang dihasilkan ekstrak kulit Manggis.

\section{SIMPULAN}

1. Ekstrak Kulit Manggis memiliki daya hambat terhadap Streptococcus mutans.

2. Luas zona hambat ekstrak kulit manggis lebih kecil daripada luas zona hambat kontrol positif yaitu Amoksisilin sehingga dapat diperlukan penelitian yang lebih lanjut tentang manfaat dari ekstrak kulit manggis.

\section{SARAN}

1. Diharapkan dapat perlu dikembangkan penelitian lebih lanjut tentang berbagai teknik ektraksi kulit manggis yang lebih memaksimalkan daya hambat yang sebenarnya dari kulit manggis.

2. Diharapkan dapat dilakukan penelitian lebih lanjut tentang ekstrak kulit manggis terhadap berbagai jenis bakteri dalam gigi dan mulut.

3. Diharapkan ekstrak kulit manggis dapat menjadi salah satu bahan dasar sebagai obat dalam pencegahan karies pada gigi.

\section{DAFTAR PUSTAKA}

1. Nugroho AE. Manggis (Garcinia mangostana L.) Dari Kulit Buah yang Terbuang Hingga Menjadi Kandidat Suatu Obat.Laboratorium Farmakologi dan Toksikologi, Bagian Farmakologi dan Farmasi Klinik, Fakultas Farmasi, Universitas Gadjah Mada. Jogjakarta.2009

2. Handoyo LE, Dahsyatnya Kulit Buah \& Tanaman Pembasmi Berbagai Penyakit. Cetakan I, Penerbit Padi. Jakarta.2014

3. Rahma SA, Suharti, Subandi. Uji Antibakteri Daya Inhibisi Ekstrak Kulit Manggis (Garcinia Mangostana L.) Terhadap Aktivits Xantin Oksidase Yang Diisolasi Dari Air Susu Sapi Segar. Tersedia dalam : http://jurnal-

online.um.ac.id/data/artikel/artikel3F DC0302488940055051C8A8B4E96F D9.pdf . Diakses tanggal : 7 Oktober 2014.

4. Muslichah S, Anggraini D, Waluyo J. Uji Aktivitas Antibakteri Ekstrak Etil Asetat Kulit Buah Manggis (Garcinia mangostana L.) Terhadap Streptococcus mutans. Available from:

http://library.unej.ac.id/client/en_US/ default/search/asset/412?dt=list Diakses tanggal : 11 Oktober 2014

5. Mardiana L. Ramuan dan Khasiat Kulit Manggis. Penebar Swadaya. Jakarta. 2011

6. Radiah, Mintjelungan CN, Mariati NW. Gambaran status karies dan pola pemeliharaan kesehatan gigi dan mulut pada mahasiswa asal Ternate di Manado. Journal e-Gigi. 2013; 1(1): p. 45

7. Nishimura J, Saito T, Yoneyama H, Bai LL, Okumura K, Isogai E. Biofilm formation by streptococcus mutans and related bacteria. Advances in Microbiology 2012 Sept; (2).p.20815.

8. Nugraha WA. Si Plak Dimana Mana. Fakultas Farmasi USD Yogyakarta 
2008;1.p.1-4.

9. Kidd EAM, Joyston S. Pencegahan karies dengan pengendalian plak. Dalam: Narlan Sumawinata, Safrida Faruk. Dasar-dasar karies: Penyakit dan penanggulangannya. Jakarta: EGC;1992. P. 141-54

10.Yunitasari L, Gempur 41 Penyakit dengan Buah Manggis Khasiat dan Cara Pengolahannya untuk Pengobatan. Cetakan I. Penerbit Pustaka Baru Press.2011.
11.Fanany B, Khasiat Selangit Ramuan Daun Sirsak Kulit Manggis Mengkudu Tumpas Beragam Penyakit Kronis.Cetakan I. Penerbit Araska. 2013.

12.Putra NK. Aktivitas Antibakteri Ekstrak Kulit Buah Manggis (Garcinia Mangostana L.) Serta Kandungan Senyawa Aktifnya, Fakultas Teknologi Pertanian Universitas Udayana. Bali. 2010. 